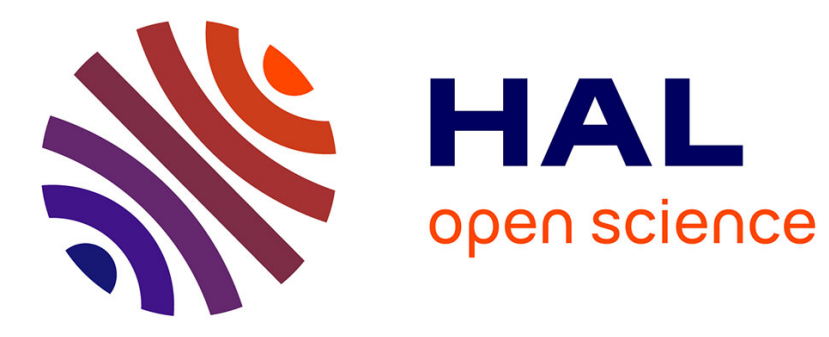

\title{
The effects of convection on the summertime mid-latitude overworld
}

\author{
A. E. Dessler
}

\section{To cite this version:}

A. E. Dessler. The effects of convection on the summertime mid-latitude overworld. Atmospheric Chemistry and Physics Discussions, 2006, 6 (5), pp.8421-8433. hal-00302096

\section{HAL Id: hal-00302096 https://hal.science/hal-00302096}

Submitted on 4 Sep 2006

HAL is a multi-disciplinary open access archive for the deposit and dissemination of scientific research documents, whether they are published or not. The documents may come from teaching and research institutions in France or abroad, or from public or private research centers.
L'archive ouverte pluridisciplinaire HAL, est destinée au dépôt et à la diffusion de documents scientifiques de niveau recherche, publiés ou non, émanant des établissements d'enseignement et de recherche français ou étrangers, des laboratoires publics ou privés. 
Atmos. Chem. Phys. Discuss., 6, 8421-8433, 2006

www.atmos-chem-phys-discuss.net/6/8421/2006/

(C) Author(s) 2006. This work is licensed

under a Creative Commons License.

Convection and the summertime mid-latitude overworld

\section{The effects of convection on the summertime mid-latitude overworld}

A. E. Dessler

Dept. of Atmospheric Sciences, Texas A\&M University, TAMU 3150, College Station, TX 77843-3150, USA

Received: 18 July 2006 - Accepted: 23 August 2006 - Published: 4 September 2006

Correspondence to: A. E. Dessler (adessler@tamu.edu)

Title Page

Abstract

Conclusions

Tables

14

4

Back
Introduction

References

Figures

$\rightarrow 1$

$>$

Close

Full Screen / Esc

Printer-friendly Version

Interactive Discussion 


\section{Abstract}

Halogen Occultation Experiment measurements of $\mathrm{H}_{2} \mathrm{O}$ are used to investigate the influence of mid-latitude convection on the summertime overworld between $30^{\circ} \mathrm{N}$ and $40^{\circ} \mathrm{N}$. We find that most of the convective influence over this latitude range occurs

5 over the Asian monsoon and over North America. Over North America, the effects of convection extend to $\sim 410 \mathrm{~K}(17.5 \mathrm{~km})$. Over Asia, the effects of convection extend to $\sim 460 \mathrm{~K}(19 \mathrm{~km})$, about $50 \mathrm{~K}(1.5 \mathrm{~km})$ higher than over North America.

\section{Introduction}

Much effort has been expended over the last decade in assessing the impact of deep

convection on the extratropical lower stratosphere. Recently, the role of the northern hemisphere $(\mathrm{NH})$ summertime monsoon circulations over North America and Asia has garnered particular interest (e.g., Dessler and Sherwood, 2004; Gettelman et al., 2004; Bannister et al., 2004; Fu et al., 2006). It is now clear that summertime convection associated with these monsoons has an important impact on the chemical composition of the lowermost stratosphere (that part of the stratosphere with potential temperature $\theta<380 \mathrm{~K}$ ) in the $\mathrm{NH}$ (e.g., Poulida et al., 1996; Fischer et al., 2003; Hegglin et al., 2004; Hess, 2005).

Dessler and Sherwood (2004, hereafter DS04) showed that summertime convection plays an important role in the Northern Hemisphere $(\mathrm{NH})$ extratropical $\mathrm{H}_{2} \mathrm{O}$ budget at $380 \mathrm{~K}$, the boundary between the lowermost stratosphere and the so-called overworld (the stratosphere with $\theta>380 \mathrm{~K}$ ). In their two-dimensional model of the $380-\mathrm{K}$ surface, DS04 cast the convective tendency for $\mathrm{H}_{2} \mathrm{O}$ as a relaxation toward a target concentration $\left[\mathrm{H}_{2} \mathrm{O}\right]_{C}$ with a time constant $\tau_{C}$ :

$$
\frac{\partial\left[\mathrm{H}_{2} \mathrm{O}\right]}{\partial t}=\frac{1}{\tau_{c}}\left(\left[\mathrm{H}_{2} \mathrm{O}\right]_{C}-\left[\mathrm{H}_{2} \mathrm{O}\right]\right)
$$

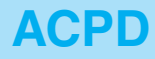

$6,8421-8433,2006$

Convection and the summertime mid-latitude overworld
A. E. Dessler

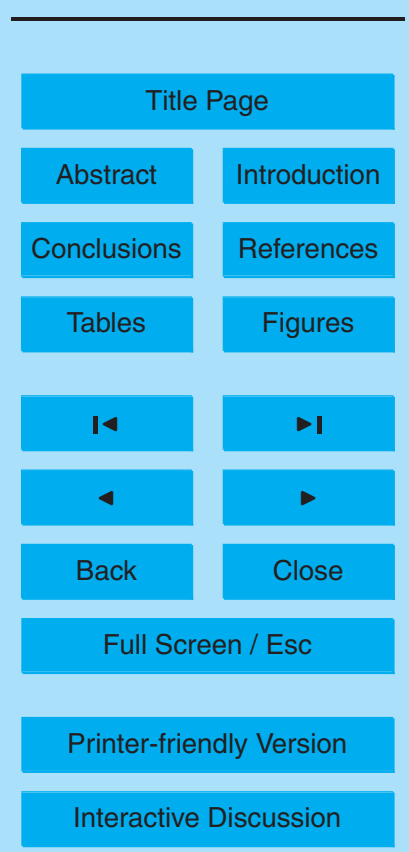


$\tau_{c}$ is the latitude- and longitude-dependent timescale with which air is convectively transported from the lower troposphere to the detrainment height, and is expected to be the same for all constituents. $\left[\mathrm{H}_{2} \mathrm{O}\right]$ is the ambient stratospheric mixing ratio, and $\left[\mathrm{H}_{2} \mathrm{O}\right]_{C}$ is the target $\mathrm{H}_{2} \mathrm{O}$ value that convection is pushing that atmosphere toward. 5 DS04 argued that $\left[\mathrm{H}_{2} \mathrm{O}_{C}\right.$ is the local saturation mixing ratio. The idea is that strong updrafts associated with deep convection can carry significant amounts of ice to the UT/LS (e.g., Alcala and Dessler, 2002; Liu and Zipser, 2005). Evaporation of ice deposited into the UT/LS will tend to drive the region toward saturation, with excess ice sedimenting out. The difference $\left[\mathrm{H}_{2} \mathrm{O}\right]_{C}$ minus $\left[\mathrm{H}_{2} \mathrm{O}\right]$ was referred to by DSO4 as the

10 "convective contrast"; it can be thought of as the effect on the $\mathrm{H}_{2} \mathrm{O}$ abundance per unit of convection. Put into their model, this simple parameterization was able to accurately reproduce the $380-\mathrm{K} \mathrm{H}_{2} \mathrm{O}$ distribution, while a model without it could not.

The mass flux to the $380-\mathrm{K}$ surface is small. However, because the $380-\mathrm{K}$ surface is so warm in the mid-latitudes, the convective contrast is large so DS04 concluded 15 that even a small amount of convection can transport significant amounts of $\mathrm{H}_{2} \mathrm{O}$ to the 380-K surface. DS04 also showed that convection has a minor impact on $\mathrm{O}_{3}$ because the convective contrast for $\mathrm{O}_{3}$ is small at all latitudes.

An unanswered question in DS04 was how high the impact of convection on the $\mathrm{H}_{2} \mathrm{O}$ budget extends. In this paper, we investigate that question.

\section{Data}

To address this issue, we will use measurements of $\mathrm{H}_{2} \mathrm{O}$ made by the Halogen Occultation Experiment (HALOE), which was carried aboard the Upper Atmosphere Research Satellite (e.g., Dessler et al., 1998). HALOE version 19 data are used here, and these $\mathrm{H}_{2} \mathrm{O}$ data have systematic errors in the lower stratosphere of $20 \%$ (Harries et al., 1996; SPARC, 2000). Constituents are retrieved on a high-resolution grid of 48 levels per pressure decade, with 23 levels between $150 \mathrm{hPa}(355 \mathrm{~K})$ and $50 \mathrm{hPa}(500 \mathrm{~K})$. The $\theta$ of each measurement is determined using daily temperature and pressure fields from

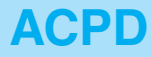

$6,8421-8433,2006$

Convection and the summertime mid-latitude overworld
A. E. Dessler

\section{Title Page}

Abstract Introduction

Conclusions

Tables References Figures

14

4

Back

Close

Full Screen / Esc

Printer-friendly Version

Interactive Discussion 
the National Center for Environmental Prediction (NCEP) that are provided with the HALOE data. $\mathrm{H}_{2} \mathrm{O}$ values at particular $\theta$ values are obtained by linear interpolation. With uncertainties in the NCEP temperatures of $\sim 1 \mathrm{~K}$, the uncertainty in the calculated $\theta$ is $\sim 2 \mathrm{~K}$, negligible for this analysis.

5 The HALOE science team has suggested (E. E. Remsberg, personal communication, 2004) that HALOE $\mathrm{H}_{2} \mathrm{O}$ measurements be adjusted to account for an altitudedependent low bias (SPARC, 2000, Sect. 2.3.1). We follow their guidance in making this adjustment: we have multiplied the HALOE $\mathrm{H}_{2} \mathrm{O}$ vmr by factors of $1.20,1.20,1.10$, and 1.05 for pressure levels of $215,121,100$ to 68 , and $56 \mathrm{hPa}$, respectively; factors

10 for levels between these are determined by log-linear interpolation. This adjustment has no impact on the conclusions of this paper.

\section{Depth of penetration of convection into the overworld}

For context, we plot in Fig. 1 the average $\mathrm{H}_{2} \mathrm{O}$ at $380 \mathrm{~K}$ measured by the HALOE between 15 June and 15 August of 1994 through 2005; similar plots appeared in DS04 15 and Randel et al. (2001). The data show maxima in $\mathrm{H}_{2} \mathrm{O}$ between $30^{\circ} \mathrm{N}$ and $40^{\circ} \mathrm{N}$ over North America and Asia. DS04 quantitatively connected these $380-\mathrm{K}$ maxima to deep convection, arguing that convection moistens the lower stratosphere in regions where the relative humidity is low. In these regions, the convective contrast is large and even a relatively small convective mass flux can lead to significant moistening.

20 We focus here on $30^{\circ} \mathrm{N}-40^{\circ} \mathrm{N}$ during the $\mathrm{NH}$ summer - the latitude band and time period where the convective anomalies identified in Fig. 1 occur. To determine the impact of convection here, we calculate the zonal variations in $\mathrm{HALOE} \mathrm{H}_{2} \mathrm{O}$ measurements. Figure 2 shows how this is done. The top panel shows the HALOE data at $410 \mathrm{~K}$ obtained between 15 June and 15 August of 1994 through 2005 and between $2530^{\circ} \mathrm{N}$ and $40^{\circ} \mathrm{N}$. These HALOE data are then separated into 30 longitude bins and the average of each bin is calculated, and this is plotted as the solid line in the top panel of Fig. 2. The anomaly, plotted in the bottom panel of Fig. 2, is calculated by subtracting

Convection and the summertime mid-latitude overworld
A. E. Dessler

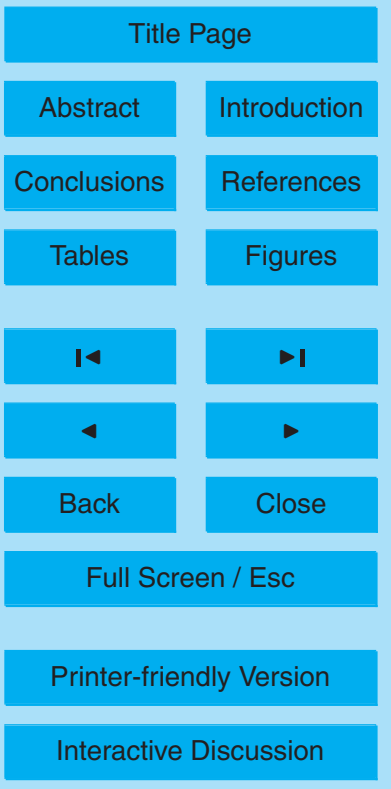

EGU 
the lowest-value bin from all of the bins. In this case, the lowest-value bin is centered at $162^{\circ}$ longitude and has a value of $4.57 \mathrm{ppmv}$. The anomaly clearly shows that $\mathrm{H}_{2} \mathrm{O}$ is higher at $60^{\circ}$ and $270^{\circ}$ longitude.

We repeat this process between 370 and $470 \mathrm{~K}$ and plot the resulting anomalies in 5 Fig. 3 as a function of $\theta$ and longitude. Consistent with the 410-K data in Fig. 2, Fig. 3 shows that there are two longitudes where large $\mathrm{H}_{2} \mathrm{O}$ anomalies exist: around $50^{\circ}$ longitude, over the Asian monsoon, and around $270^{\circ}$ longitude, over North America. This is also consistent with Fig. 1, and is anyway not surprising since these regions are well known to be the site of vigorous deep convection. Over North America (270 Ion10 gitude), the anomaly decreases monotonically with height, from $\sim 0.65 \mathrm{ppmv}$ at $380 \mathrm{~K}$ $(15.5 \mathrm{~km})$ to $\sim 0.1 \mathrm{ppmv}$ at $410 \mathrm{~K}(17.5 \mathrm{~km})$. This should not be taken to mean that convective detrainment does not occur at higher altitudes: in situ data taken over North America (Hanisco et al., 2006 ${ }^{1}$ ) show evidence of convective detrainment as high as $430 \mathrm{~K}$. However, we speculate that such high-altitude detrainment occur infrequently enough that its effects cannot be discerned by this analysis.

Over Asia $\left(50^{\circ}\right.$ longitude), the anomaly also decreases monotonically with height, from $\sim 0.60 \mathrm{ppmv}$ at $380 \mathrm{~K}(15.5 \mathrm{~km})$ to $\sim 0.1 \mathrm{ppmv}$ at $460 \mathrm{~K}(19 \mathrm{~km})$. Thus, the anomaly over North American and Asia are of similar magnitude at $380 \mathrm{~K}$, but the convective anomaly over the Asian monsoon extends about $50 \mathrm{~K}(1.5 \mathrm{~km})$ higher than the North 20 American convection anomaly. This is not unexpected because, by most metrics, convection over the Asian monsoon is far stronger than over North America (e.g., Dunkerton, 1995).

We can immediately rule out a photochemical explanation for the pattern in Fig. 3 because the lifetimes of $\mathrm{H}_{2} \mathrm{O}, \mathrm{CH}_{4}$, and $\mathrm{H}_{2}$ at these altitudes are decades (e.g., Dessler, 2000). A more plausible explanation is meridional advection of high $\mathrm{H}_{2} \mathrm{O}$ from either lower or higher latitudes. We can rule this out, also. Figure 1 shows that this is impossi-

\footnotetext{
${ }^{1}$ Hanisco, T. F., Moyer, E. J., Weinstock, E. M., et al.: Observations of deep convective influence on stratospheric water vapor and its isotopic composition, Geophys. Res. Lett., submitted, 2006.
}

Convection and the summertime mid-latitude overworld

A. E. Dessler

Title Page

Abstract Introduction

Conclusions

Tables References

Figures

14

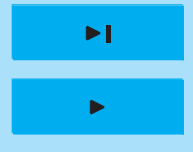

4

Back

Close

Full Screen / Esc

Printer-friendly Version

Interactive Discussion 
ble at $380 \mathrm{~K}: \mathrm{H}_{2} \mathrm{O}$ is lower both poleward and equatorward of the mid-latitude maxima, so meridional advection cannot explain the maxima. To show this is also true at other $\theta$, we plot in Fig. 4 a latitude-height cross-section through the Asian monsoon. The crosses indicate the latitude of maximum $\mathrm{H}_{2} \mathrm{O}$ on selected $\theta$ levels. This plot shows 5 that between 380 and $450 \mathrm{~K}, \mathrm{H}_{2} \mathrm{O}$ between $30^{\circ} \mathrm{N}-40^{\circ} \mathrm{N}$ is higher than air both poleward and equatorward. Thus, meridional transport cannot be responsible for the high $\mathrm{H}_{2} \mathrm{O}$ found there.

Finally, we can rule out downward transport because $\mathrm{H}_{2} \mathrm{O}$ tends to decrease with increasing $\theta$ in this season and over the $\theta$ range of interest here. We also note that

10 it is unlikely that problems in the HALOE data are responsible. The pattern in Fig. 3 would require longitude-dependent biases, and there is no evidence to support the existence of such biases. We conclude that only upward transport can explain the $\mathrm{H}_{2} \mathrm{O}$ anomalies, and that the only possible explanation for this upward transport is convection.

15 While convection reaching the overworld, even as high as $460 \mathrm{~K}$, might seem surprising, previous studies provide anecdotal evidence to support this conclusion. Fromm et al. (2000) reported several occurrences of forest fire smoke in the overworld, while Fromm and Servranckx (2003) described observations of forest fire smoke as high as $460 \mathrm{~K}$. Wang et al. (2003) has modeled summertime continental convection and has simulated convection reaching $\theta>400 \mathrm{~K}$, well into the overworld. Several studies have used biomass burning products as signatures of recent convection. Livesey et al. (2004) observed a biomass burning product, methyl cyanide, at 100-68 hPa (16$19 \mathrm{~km}$ or $400-450 \mathrm{~K}$ ) in the summertime $\mathrm{NH}$ mid-latitudes. In situ data analyzed by Jost et al. (2004) showed biomass burning products at altitudes between 380 and $400 \mathrm{~K}$. We should note that it is possible that the final $\theta$ of biomass products is higher because of radiative lofting of a smoke-filled plume after detrainment, which would not affect plumes containing no smoke.

While Fig. 3 tells where convection is important, we believe that one cannot quantitatively assess the impact of convection from the figure. Model runs with the DS04

Convection and the summertime mid-latitude overworld
A. E. Dessler

Title Page

Abstract

Conclusions

Tables

Figures

14

4

Back

Introduction

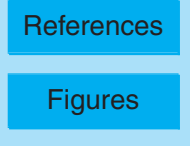

$>1$

Close

Full Screen / Esc

Printer-friendly Version

Interactive Discussion 
model suggest that the effects of convection over North America and Asia are transported zonally throughout the latitude band, so the entire latitude band is contaminated by convection. If the DS04 model is correct on this point, then the impact of convection on this latitude band is larger than the perturbations observed in the convective regions 5 of Fig. 3. We are presently pursuing other approaches to determine quantitatively by how much convection increases the $\mathrm{NH}$ summertime extratropical overworld.

Several papers (e.g., Dessler and Sherwood, 2004; Gettelman et al., 2004; Bannister et al., 2004; Fu et al., 2006) have discussed how this monsoonal circulation provides a pathway for air to enter the overworld without passing through the tropical tropopause 10 cold-point, which is usually found below $380 \mathrm{~K}$. Our work is consistent with this idea. We see significant transport of $\mathrm{H}_{2} \mathrm{O}$ by mid-latitude convection to $\theta$ levels above $380 \mathrm{~K}$. This transport does indeed bypass the tropical cold-point. If this air is subsequently transported equatorward and lofted up into the stratosphere, it could possibly perturb the abundance of water throughout the stratosphere.

\section{Conclusions}

We have used HALOE $\mathrm{H}_{2} \mathrm{O}$ measurements to investigate the influence of extratropical convection on the summertime overworld between $30^{\circ} \mathrm{N}$ and $40^{\circ} \mathrm{N}$. We find that most of this convection occurs over the Asian monsoon and over North America. Over North America, the effects of convection extend to $\sim 410 \mathrm{~K}(17.5 \mathrm{~km})$. Over Asia, the effects 20 of convection extend to $\sim 460 \mathrm{~K}(19 \mathrm{~km})$, about $50 \mathrm{~K}(1.5 \mathrm{~km})$ higher than over North America.

Acknowledgements. This work was supported by NASA ACMAP grant NNG04GF26G to Texas A\&M University. We acknowledge help interpreting the HALOE data from Ellis Remsberg and useful comments on the manuscript from $E$. Jensen.

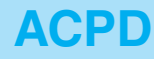

$6,8421-8433,2006$

Convection and the summertime mid-latitude overworld
A. E. Dessler

Title Page

Abstract

Introduction

Conclusions

Tables

References

Figures

14

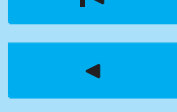

$>1$

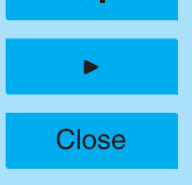

Full Screen / Esc

Printer-friendly Version

Interactive Discussion 


\section{References}

Alcala, C. M. and Dessler, A. E.: Observations of deep convection in the tropics using the TRMM precipitation radar, J. Geophys. Res., 107, 4792, doi:10.129/2002JD002457, 2002.

Bannister, R., O'Neill, A., Gregory, A., and Nissen, K.: The role of the south-east Asian monsoon and other seasonal features in creating the "tape-recorder" signal in the Unified Model, Q. J. R. Meteorol. Soc., 130, 1531-1554, 2004.

Dessler, A. E.: The chemistry and physics of stratospheric ozone, 214 pp., Academic Press, San Diego, 2000.

Dessler, A. E., Burrage, M. D., Grooss, J.-U., Holton, J. R., Lean, J. L., Massie, S. T., Schoeberl, M. R., Douglass, A. R., and Jackman, C. H.: Selected science highlights from the first five years of the Upper Atmosphere Research Satellite (UARS) program, Rev. Geophys., 36, 183-210, 1998.

Dessler, A. E. and Sherwood, S. C.: The effect of convection on the summertime extratropical lower stratosphere, J. Geophys. Res., 109, D23301, doi:10.1029/2004JD005209, 2004.

15 Dunkerton, T. J.: Evidence of meridional motion in the summer lower stratosphere adjacent to monsoon regions, J. Geophys. Res., 100, 16 675-16 688, 1995.

Fischer, H., de Reus, M., Traubet, M., et al.: Deep convective injection of boundary layer air into the lowermost stratosphere at midlatitudes, Atmos. Chem. Phys., 3, 739-745, 2003.

Fromm, M., Alfred, J., Hoppel, K., Hornstein, J., Bevilacqua, R., Shettle, E., Servranckx, R., Li, Z. Q., and Stocks, B.: Observations of boreal forest fire smoke in the stratosphere by POAM III, SAGE II, and lidar in 1998, Geophys. Res. Lett., 27, 1407-1410, 2000.

Fromm, M. D. and Servranckx, R.: Transport of forest fire smoke above the tropopause by supercell convection, Geophys. Res. Lett., 30, 1542, doi:10.1029/2002GL016820, 2003.

Fu, R., Hu, Y. L., Wright, J. S., et al.: Short circuit of water vapor and polluted air to the global stratosphere by convective transport over the Tibetan Plateau, Proc. Natl. Acad. Sci., 103, 5664-5669, 2006.

Gettelman, A., Kinnison, D. E., Dunkerton, T. J., and Brasseur, G. P.: Impact of monsoon circulations on the upper troposphere and lower stratosphere, J. Geophys. Res., 109, D22101, doi:10.1029/2004JD004878, 2004.

30 Harries, J. E., Russell III, J. M., Tuck, A. F., et al.: Validation of measurements of water vapor from the Halogen Occultation Experiment (HALOE), J. Geophys. Res., 101, 10205-10216, 1996.

Convection and the summertime mid-latitude overworld

A. E. Dessler

Title Page

Abstract

Introduction

Conclusions

Tables

References

Figures

14

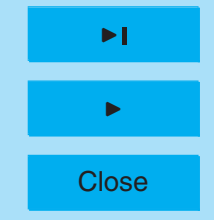

Full Screen / Esc

Printer-friendly Version

Interactive Discussion 
Hegglin, M. I., Brunner, D., Wernliet, H., et al.: Tracing troposphere-to-stratosphere transport above a mid-latitude deep convective system, Atmos. Chem. Phys., 4, 741-756, 2004.

Hess, P.G.: A comparison of two paradigms: The relative global roles of moist convective versus nonconvective transport, J. Geophys. Res., 110, D20302, doi:10.1029/2004JD005456, 2005.

5 Jost, H.-J., Drdla, K., Stohl, A., et al.: In-situ observations of mid-latitude forest fire plumes deep in the stratosphere, Geophys. Res. Lett., 31, L11101, doi:10.1029/2003GL019253, 2004.

Liu, C. and Zipser, E. J.: Global distribution of convection penetrating the tropical tropopause, J. Geophys. Res., 110, D23104, doi:10.1029/2005JD006063, 2005.

Livesey, N. J., Fromm, M. D., Waters, J. W., Manney, G. L., Santee, M. L., and Read, W. G.: Enhancements in lower stratospheric $\mathrm{CH}_{3} \mathrm{CN}$ observed by the Upper Atmosphere Research Satellite Microwave Limb Sounder following boreal forest fires, J. Geophys. Res., 109, D06308, doi:10.1029/2003JD004055, 2004.

Poulida, O., Dickerson, R. R., and Heymsfield, A.: Stratosphere-troposphere exchange in a midlatitude mesoscale convective complex, 1. Observations, J. Geophys. Res., 101, 682315 6836, 1996.

Randel, W. J., Wu, F., Gettelman, A., Russell III, J. M., Zawodny, J. M., and Oltmans, S. J.: Seasonal variation of water vapor in the lower stratosphere observed in Halogen Occultation Experiment data, J. Geophys. Res., 106, 14 313-14 325, 2001.

SPARC Report $\mathrm{N}^{\circ} 2$, SPARC Assessment of Upper Tropospheric and Stratospheric Water Vapour, December 2000.

Wang, P. K.: Moisture plumes above thunderstorm anvils and their contributions to crosstropopause transport of water vapor in midlatitudes, J. Geophys. Res., 108, 4194, doi:10.1029/2002JD002581, 2003.

\section{ACPD}

$6,8421-8433,2006$

Convection and the summertime mid-latitude overworld
A. E. Dessler

\section{Title Page}

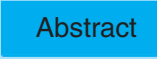

Introduction

Conclusions

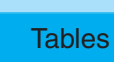

References

Tables

Figures

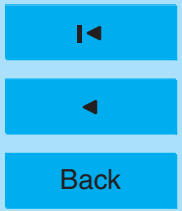

$>1$

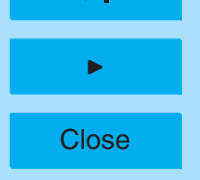

Full Screen / Esc

Printer-friendly Version

Interactive Discussion 


\section{ACPD}

6, 8421-8433, 2006

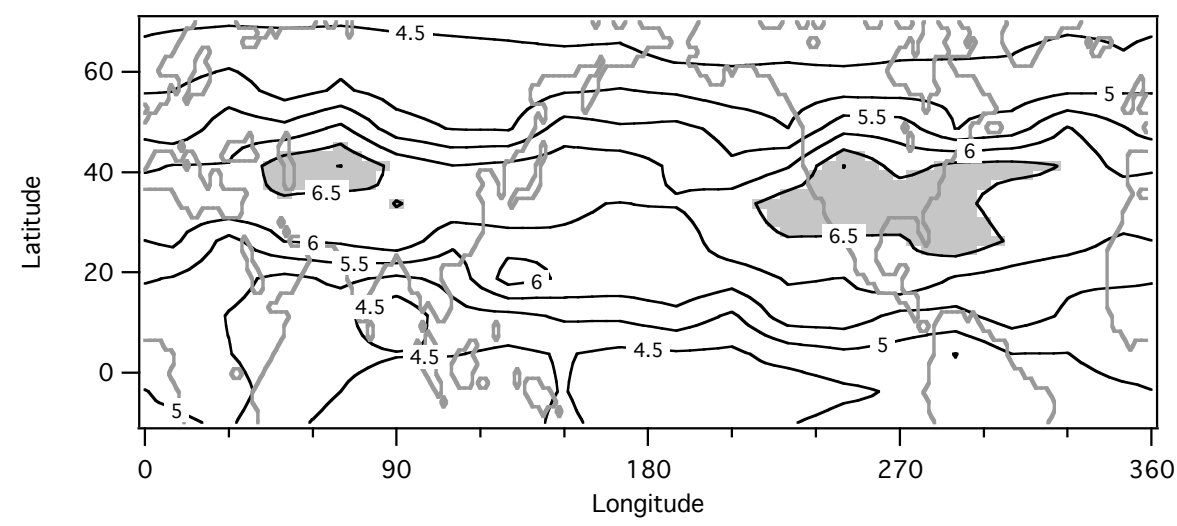

Convection and the summertime mid-latitude overworld
A. E. Dessler

Title Page

Fig. 1. Distribution of $\mathrm{H}_{2} \mathrm{O}$ at $380-\mathrm{K} \theta$ measured by the HALOE between 15 June and 15 August of 1994-2005. Units are ppmv, and regions $>6.5$ ppmv are shaded.

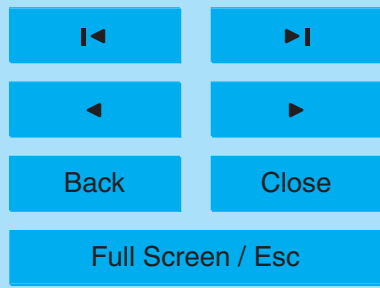

Printer-friendly Version 


\section{ACPD}

\section{6, 8421-8433, 2006}

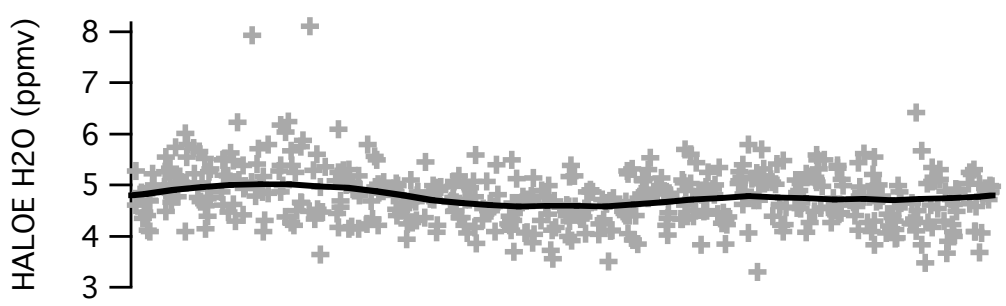

Convection and the summertime mid-latitude overworld
A. E. Dessler

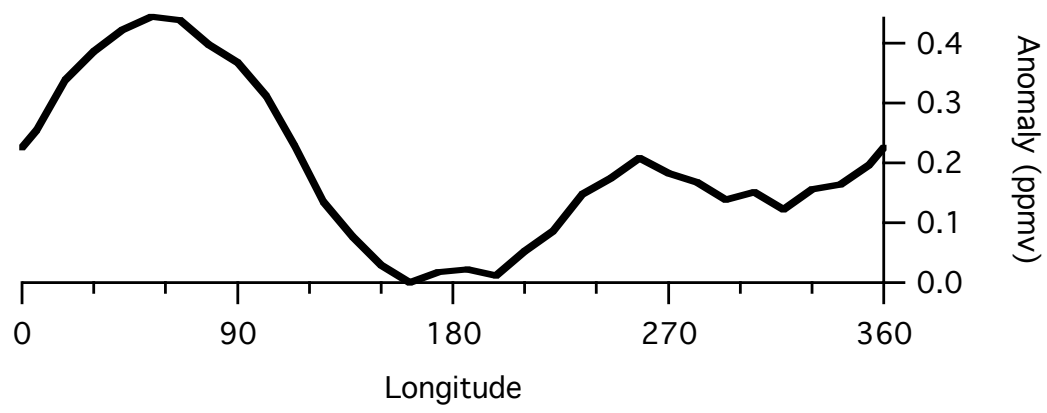

Title Page

Abstract

Introduction

Conclusions

References

Tables

Figures

14

I

4

Back

Full Screen / Esc

Printer-friendly Version

Interactive Discussion 


\section{ACPD}

6, 8421-8433, 2006

\section{Convection and the} summertime mid-latitude overworld

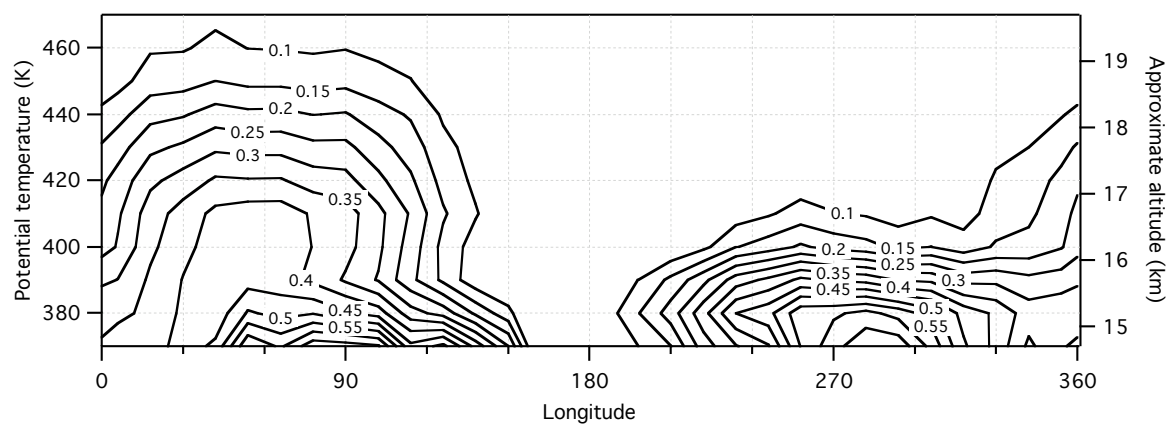
A. E. Dessler

\section{Title Page}

\section{Abstract}

Conclusions

\section{Tables}

Fig. 3. $\mathrm{H}_{2} \mathrm{O}$ anomaly as a function of $\theta$ and longitude. See text for details of how the anomaly is calculated. HALOE measurements were obtained between $30^{\circ} \mathrm{N}$ and $40^{\circ} \mathrm{N}$ and between 15 June and 15 August of 1994-2005.
14
4

Back

\section{Introduction}

References

Figures

$\rightarrow$

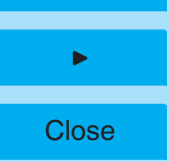

Full Screen / Esc

Printer-friendly Version 


\section{ACPD}

\section{6, 8421-8433, 2006}

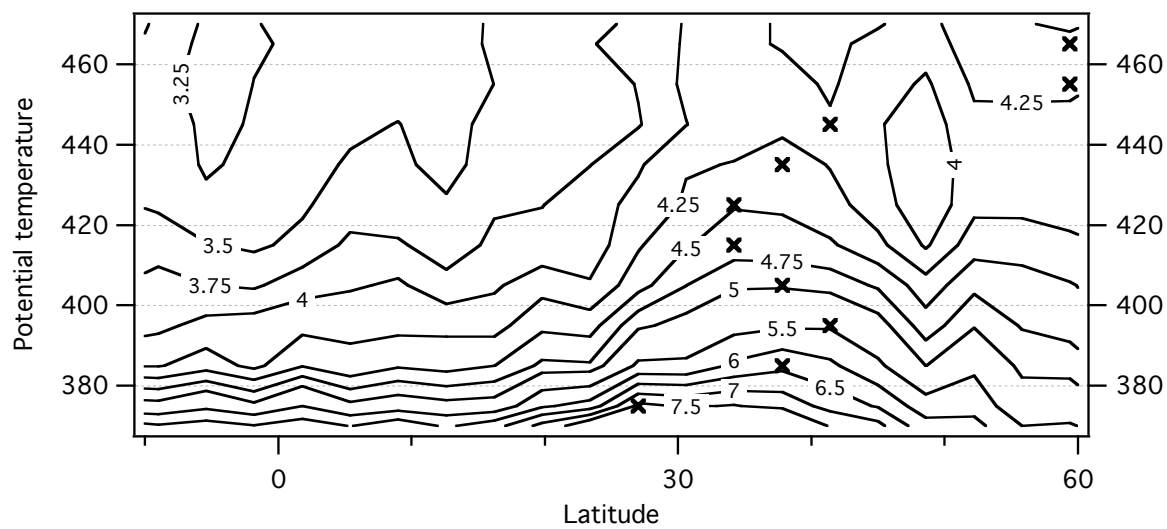

Convection and the summertime mid-latitude overworld
A. E. Dessler

\section{Title Page}

\section{Abstract}

Conclusions

\section{Tables}

14

4

Back
Introduction

References

Figures

$\rightarrow$ crosses indicate the latitude where $\mathrm{H}_{2} \mathrm{O}$ on that theta surface is a maximum. Contour interval is 0.25 ppmv below 5 ppmv and 0.5 ppmv above 5 ppmv. HALOE measurements were obtained between $30^{\circ} \mathrm{N}$ and $40^{\circ} \mathrm{N}$ and between 15 June and 15 August of 1994-2005.

\section{Full Screen / Esc}

Printer-friendly Version 